\title{
The Palace of Illusions-Voice of a Disillusioned Woman
}

\author{
Abisha S. V \\ PG and Research Dept of English \\ Fatima Mata National College (Autonomous) \\ Kollam, Kerala, India
}

Dr. Cynthia Catherine Michael

Assoc Prof \& Head

PG and Research Dept of English

Fatima Mata National College (Autonomous)

Kollam, Kerala, India

cynthiamichae12006@yahoo.com

\begin{abstract}
Diaspora writing is a recent trend in literature. Many writers especially women writers excel in this field. These diasporic writers though they live in a foreign land always hold their love in their writings. India is a land of myth and legends and hence many Indian writers borrow their plot from Hindu mythology which is used as a literary device. Many writers of the independence and post-independence era used mythology to spread nationalism and to guide humanity in the right path. Chitra Banerjee Divakaruni is a diasporic writer who always holds a piece of her love for motherland in her writings. She extensively uses Hindu mythology in her works. She uses these myths to instill courage in her woman protagonists. She tries to prove how myths guide the immigrant women to overcome their conflicts in life. Her novels explain how myths instruct the humanity to lead a righteous life.
\end{abstract}


Keywords: Imagination, Polygamy, History, Identity, Alienation.

The art of storytelling has been there since the growth of the mankind. He narrates the stories to his children coloring them with his imagination. In literature, the writers use different narrative techniques to tell a story to the readers. The story could be fairy tales, mysteries, fantasies, horrors, romances, historic fiction etc. They can be imaginary or factual or a combination of both. Non-linear narrative is one of the narrative techniques used by the writers. It often uses flashbacks in which past or future events are revealed through memories or telling another story in the main plot. It follows a chronological order sometimes explaining dreams or stream of consciousness narrative. There are many writers in Indian writing in English fiction especially women writers who express their caliber in this realm of literature. They belong to the younger generations of the era who emerged in the postcolonial diasporic writing following the footsteps of Salman Rushdie and Bharati Mukherjee. Indian writing is rich with the wealth of materials taken from the great Indian epics like Mahabharata and the Ramayana and the folk lore and legends of the early communities. The writers of the Indian English knowingly or unknowingly mention the Puranas in their stories as a source of inspiration. The works of R.K.Narayan and Raja Rao are the best examples in this genre.

Among the women diasporic writers Chitra Banerjee Divakaruni has a unique place in literature. Chitra Banerjee Divakaruni, the author of seven novels, has shocked the literary canon of 1990s with her magical realistic novels. She was a poet and a writer working in a non-profitable organization that helps women especially the immigrant South Asian women. She writes children's stories and also about women issues. She uses magical realism, myth, identity crisis, alienation in her novels. All her writings lend grandeur to the novels. One of her novels is The Palace of Illusions published in 2008.The novel is narrated in a first-person narrative. As in all of her novels, this novel is also dominated with a strong woman character. 
In fact, Divakaruni tries to retell the story of Mahabharata in a woman's point of view i.e., according to Draupadi, the wife of Pandavas. Thus, Divakaruni breaks down the stereotype of myths dominated by men into women dominated. The novel is the writing in the genre of epic fantasy and mythological fiction which gives it a feminine narrative. Mahabharata is a great epic of India that tells us the story of the war between Kauravas and Pandavas and Lord Krishna's teachings to the great warrior Arjuna and the destruction of the Third Age of man. As all myths do, the epic Mahabharata also teaches mankind to do right thing. But the twist in the plot of Divakaruni is she concentrates on Draupadi, the one who is characterized as the cause of all bad lucks in the epic. Divakaruni gives a strong voice to Draupadi making her the lead and portrays Mahabharata in a feminine perspective. The novel shows how Draupadi could change the course of history and being the cause of the greatest war that the world has ever seen. The title of the novel is a general metaphor of life. Humans continue their life through many humiliations, trials and tribulations, sustains his desires and surrounds by illusions or Maya and when that illusion breaks enlightenment comes. The novel is real and magic at the same time.

The novel begins with the birth of Draupadi and her brother Dhri. Drupad, King of Panchaal, wants to get revenge on his friend Drona and prays to the Gods for a son. He conducts a hundred days fast and prayers. At the end of the hundred day's puja, from the yagna a boy was born and holding the boy's legs a girl was also born which was unexpected and that is Draupadi (daughter of Draupad) or Panchaali (Queen of Panchaal). Under the care of Dhai Ma, Draupadi grows and knows about the outside world. The patriarchal society is reflected through the words of Draupadi and her constant struggles to get away from them. She secretly learns the Vedas that are taught to her brother Dhri and learns about war and how to fight in a battle. She secretly learns all these because she was not allowed to learn the things that are mentioned for men. Instead she was trained to do women chores. When she 
happened to visit Ved Vyas, he advises her to control her emotions and words that would cause her disaster in the future and also prophesied that she would change the history and would be the cause of a great war. As said Draupadi's actions were said to be the rootcause for all her bad lucks. At her Swamyamvara, she humiliated Karna by asking him about his family even though she secretly falls in love with him. As Krishna advised, she married Arjuna, brother of the Pandavas. Because of Kunti's decision, all five Pandavas have to marry Draupadi and hence she became the wife of five brothers, may be the first woman to adopt polygamy. When the Pandavas got their rightful share, Draupadi got the status of a queen. With the help of Maya, the chief architect, Draupadi became the owner of a palace called Palace of Illusions. When the Kauravas visit the palace, Duryothana accidentally slips and one of the Draupadi's servants laughs that make Kauravas angry. At the Kauravas court, Yudhistir gambles and lost all of his wealth and they humiliated Draupadi by taking away her saree. Lord Krishna saves her from that insult and Draupadi took an oath that she would never comb her hair unless she bathes it in Kauravas' blood. That became the cause of the great Kurukshetra war.

The novel clearly depicts how Draupadi changed the course of history. In the beginning itself we can see the typical patriarchal society. King Drupad grows Dhri for a mission to take revenge on Drona. Hence, he was trained in all Vedas and battle strategies. On the other hand, Draupadi was asked to do knitting, cleaning and all other women chores. As she was born out of fire, she was dark in color yet beautiful. Her interpretation and redefinition of her beauty especially her resemblance with the skin tone of Lord Krishna is an important aspect of the novel. The other wives of King Draupad refused to talk with Draupadi and kept their children away from her. Only Lord Krishna and her brother, Dhri were her best companions. She had an enigmatic relationship with Krishna and it is beautifully portrayed in the novel. More than a friend Krishna is her everything. The real purpose of Krishna is 
depicted at the end of the novel when Pandavas and Draupadi were on their way to heaven. From the beginning Draupadi shows all the suffocated feelings of women. She fell in love with Karna's portrait at first but Lord Krishna intervened and asked her to see the portrait of Arjuna. Being born in a low caste family, Karna was rejected as a suitor for Draupadi. But she secretly holds her feelings for him in her heart until she learns that Karna was also born to Kunti. Thus Draupadi became the paramour for all the Pandavas. In all her actions she tries to be a good daughter, friend, sister and a dutiful wife and daughter-in-law. When the Pandavas were in exile, it was Draupadi's stubbornness that made her husbands to fight back and gave Kauravas a right answer for insulting her in front of all people.

Divakaruni portrays Draupadi as one who belongs to an ancient time with modern and revolutionary thoughts. Infact she is so modern than the women in the present. She is very stubborn and stands against wrong and firmly stands on her will. There are instances where Draupadi confronts others. She boldly questions Karna at her swayamvara, questions the teacher about women being restricted from learning Vedas and wars that became the cause of the death of Keechak who raped many women. In her actions of getting revenge and stubbornness she is truly revolutionary. The novel shows the different aspects of Draupadi. Her rebellious nature to learn what her brother has learnt, her shock at knowing the prophecy that she would marry five men and change the course of history, her secret love for Karna, her constant equation with Krishna and her brother Dhri, her bond with Dhai Ma, Kunti and other wives of her husband. Her remorse and anger at being ashamed at the court of Kauravas, her stubbornness to make her husbands fight to restore her lost honor resulting in the battle of Kurukshetra and her dream to have a palace of her own. Her realization that the war was futile, her pain at losing loved ones, her efforts to bring all the women together to stand on their own feet after the war and finally departing for the other world as a mark of 
repentance and renunciation. Thus, the novel presents the feelings of Draupadi at every stage of her life.

Divakaruni depicts Draupadi as a powerful, strong and independent woman. Rather than a subservient she is considered equal to men. She presents Draupadi's life as a series of choices made by her and not the people around her. Divakaruni's interpretation of the epic gives a different view giving voice to strong woman and portraying them as equals to men. Though Divakaruni gives a strong role to women showing them more than just daughters and wives of great heroes, the injustices borne by the female at present constantly remind the reader that no matter how much women assert their independence in the society, if men believe that they are superior to women, then equality will not prevail. The boon that is granted to Draupadi that her virginity will be restored each year is not for her but for her husband's sake.There are certain instances where Draupadi is powerless and looks for help from the men around her. When she didn't get that secure and care she decided to protest and that resulted in a war for which she was blamed as a bad luck. She is referred in the epic as 'kritya' meaning one who brings destruction to his clan.

The changing phases of Draupadi are shown clearly. At one point she is all womanly and full of passion. Thinking about what to wear and how to do her hair on different occasions, obsessed with her magical palace which she built up with care with the help of Maya, growing a garden that has variety of flowers, manicuring the plants, creating magical steps and mirrors, admiring the mirrors and water, secretly holding her feelings for Karna, having an enigmatic relationship with Krishna, loving and taking care of her husbands' wives and children and at times being possessive of her husbands. These are the things Draupadi shows in the beginning. She believes war is futile and thinks war is only for men to prove their valour and woman wouldn't think that way and declares she would teach the men in her life to search for other ways to glory. But when she was insulted the blood thirsty revenge 
grasped her and war is the only thing that rings in her head. The queen who once thinks of wearing grand outfits and jewels and interested in doing different hair braids now took a severe oath not to tie her hair until she sees the end of Kauravas.

Draupadi depends on other men in her life. She marries Arjuna after the advice of Krishna and follows him without knowing anything about him; She gazes at Arjuna to speak for her when Kunti asks her sons to divide whatever Arjuna has brought and surprised that he didn't speak a word and also kept quiet for the decision taken by Kunti; looks at her husbands and finally at Karna and Bheesma to save her from the humiliation at Kaurava's court;seeks the help of Bheem to kill Keechak who tries to abuse her and finally to fulfill her vengeance she sets her husbands for the war. Though her life is depended on men in all phases of her life to fulfill the prophesied history's change Draupadi's actions have played a great role. Without her protest her vengeance could not have succeeded. In today's world there are many Draupadis who expects help from the men around them but loses the voice to protest that the ancient Draupadi has. Draupadi's husband, Yudhistir, after wagers and loses everything he owned, his brothers and himself and at last wages his wife too in the game of dice. After he loses her his enemies tries to harass her by removing her sari. Though her prayers are answered and the sari became infinitely long, no one present in the court attempts to save her from this humiliation. Though Draupadi was never raped she had received many unwanted advances by men, a common incident that seems to be prevalent in today's society. But Draupadi was courageous enough to fight off her offenders. Divakaruni tries to connect the ancient myth with modern society. Nowadays a lot of women face harassment in the public both physically and mentally but no one is there to save her or speak for her but watches her as a spectacle. They receive many unwanted advances from men but they ignore it. Though there is a numerous year's and generation's gap that separates contemporary life from 
Panchaali's, her life's events are surprisingly similar to the many trials and tribulations faced by today's women.

Though the focus of the novel The Palace of Illusions is on Draupadi's life, Divakaruni also takes the advantage of including other strong female characters just as Draupadi. Divakaruni portrays the story of Kunti, mother-in-law of Draupadi, who devoted her life to the upbringing of her own sons and the sons of her husband's second wife, making sure to treat them all equally, and grooming them as kings. She also mentions the story of Gandhari, the wife of the blind king Dhritarashtra, who also blindfolds herself, choosing to live as an equal to her husband, surrendering her power as a queen and mother. What makes Divakaruni's novel compelling above other interpretations of the novel is that she portrays all these women as conscious choices made by them not as roles handed to them by society or by the men in their lives. These women chose the lives that they lived and did not simply walk into them. To give the women of ancient India such power and freedom is phenomenal. Divakaruni's interpretation provides a humanistic touch to the epic, making it more reliable and realistic and more personal. In the words of Divakaruni "Everyone breathes in air, but it's a wise man who knows when to use that air to speak and when to exhale in silence" (wrytin.com), Draupadi stands as a symbol of actions more than words. 


\section{Works Cited}

Kala, V. "Critical analysis of Chitra Banerjee Divakaruni's The Palace of Illusions" Studymode. 3 Oct. 2013. Web. 9 Nov. 2020.

Ranjani. "Palace of Illusions-Feminist writing". Feministwords.wordpress. 2013. Web. 7 Nov. 2020.

Sahani, Anannya. "A Critical literary review of Palace of Illusions- A mythological fiction”. Wrytin. 21 May 2019. Web. 9 Nov. 2020.

Tandon, Tariqa. "The Palace of Illusions: A Book review”. Alterinter.org. 2 Jul. 2013. Web. 7 Nov. 2020. 